Génét. Sél. Evol., 1984, 16 (1), 1-14

\title{
Allozyme variation in natural populations of Lymantria dispar (Lepidoptera)
}

\author{
Caroline GEORGE \\ Laboratoire d'Evolution des Etres organisés \\ 105, boulevard Raspail, F 75006 Paris
}

\begin{abstract}
Summary
Populations of Lymantria dispar collected in France, Morocco, Canada and China are surveyed for allozyme variability in four enzymes (EST, AcPH, AAT and LAP). Over ten observed loci, the average heterozygosity is low $(\bar{H}=0.09)$. In the same forest, egg-mass progenies, collected from different host-trees, show differences in allele frequencies. Nei's standard genetic distances are calculated between populations. The distance is small $(\bar{D}=0.03)$ between the French and Canadian samples confirming the French origin of the Canadian populations. By contrast the genetic distance is large between France and Morocco $(\widetilde{D}=0.37)$ raising a question of the taxonomic and ecological differences between these populations.
\end{abstract} dispar.

Key words : Enzymatic polymorphism, geographical variation, Lepidoptera, Lymantria

\author{
Résumé \\ Variations allozymiques dans des populations naturelles \\ de Lymantria dispar (Lepidoptera)
}

Les populations de Lymantria dispar proviennent de France, du Maroc, du Canada et de Chine. Leur variabilité allozymique est étudiée sur quatre enzymes (EST, PhAC, AAT et LAP). Sur les dix locus observés, l'hétérogénéité moyenne est faible $(\overline{\mathbf{H}}=\mathbf{0 , 0 9})$. Dans la même forêt, les descendants des pontes récoltées sur des arbres d'espèces différentes montrent des écarts. La distance génétique standard de Nei est calculée entre les populations. Elle est faible entre les échantillons français et canadien $(\overline{\mathrm{D}}=0,03)$ confirmant l'origine française du peuplement canadien. Tandis que la distance génétique entre la France et le Maroc est grande $(\overline{\mathrm{D}}=0,37)$ posant la question des différences taxonomiques et écologiques entre ces deux peuplements.

Mots clés : Polymorphisme enzymatique, variation géographique, Lépidoptère, Lyman. tria dispar. 


\section{Introduction}

The gypsy moth, Lymantria dispar, is found in temperate areas extending from North Africa through Eurasia to the Japenese Islands. The insects were introduced into North America from France in the end of the 19th century (LEONARD, 1974). Although larvae are polyphagous, the oaks are by far the preferred hosts. Numerous studies, especially those of GolDSCHMIDT (1934), have described geographic variations in this species for different characters such as wing patterns, body colour, chromosomes... In particular, GoLDSCHMIDT (1934) observed the existence of sex-races showing a partial intersexuality between different geographic populations of Lymantria dispar. This paper reports the analysis of enzymatic polymorphism to estimate the genetic differentiation between populations of different geographic origins.

\section{Material and methods}

Egg-masses were collected in four countries from different host-trees, except the population of the Hérault department $(\mathbf{H})$ which consisted of field-collected larvae (tabl. 1, fig. 1). All the samples were collected in 1980 except for the Chinese one (1979). Gypsy moth larvae were hatched in the laboratory and were reared on wheat germ artificial diet. The larvae collected in the same forest from the same sort of host-tree were reared together. To study the genetic determinism, a few egg-mass progenies were reared alone (GEORGE, 1982). Electrophoresis was performed on third or fourth instar larvae taken randomly. They were ground in distilled water, centrifuged for $20 \mathrm{mn}$ at $2500 \mathrm{~g}$ at $5^{\circ} \mathrm{C}$ and the supernatants were frozen in liquid nitrogen until assayed.

The dicountinous acrylamide gel system used for disc electrophoresis by ORNSTEIN (1964) and Davies (1964) and adapted to the vertical slab technique by E-C-Apparatus Corp. (1966) was employed. The gel slab consists of a spacer gel made up of 5 p. 100 Cyanogum-41 in a $0.1 \mathrm{M}$ Tris- $\mathrm{HCl}$ buffer at $\mathrm{pH} 6.7$ and a running gel prepared with 9 p. 100 or 11 p. 100 Cyanogum-41 in a $0.5 \mathrm{M}$ Tris- $\mathrm{HCl}$ buffer at $\mathrm{pH} 8.9$. The electrode chambers were filled with $0.04 \mathrm{M}$ Tris-glycine buffer at $\mathrm{pH} 8.3$. The run was performed for 3 or 6 hours at a constant voltage of $300 \mathrm{~V}$.

Esterases (EST) were detected according to SIMON (1969) using both $\alpha$ - and $\beta$-naphthyl acetates in equal quantities as substrates; Leucine aminopeptidases (L.AP) were stained by the method of SHaw \& Prasad (1970); Acid phosphatases (AcPH) were stained using the method of PASTEUR \& KASTRITSIS (1971), modified by GIRARD (1976) ; and aspartate aminotransferases (AAT) staining was modified from MC KECHNIE et al. (1975). After staining, the gels were washed in distilled water, fixed in 7 p. 100 acetic acid solution for 48 hours and stored in plastic bags.

Alleles were designated according to the conventions set forth in Ayala et al. (1972). We arbitrarily coded as 100 the most common allele in French populations. An allele coding for an enzyme which migrates approximately $3 \mathrm{~mm}$ farther from the origin than the 100 allozyme was designated 103 , while one migrating $3 \mathrm{~mm}$ less far was designated 97. 


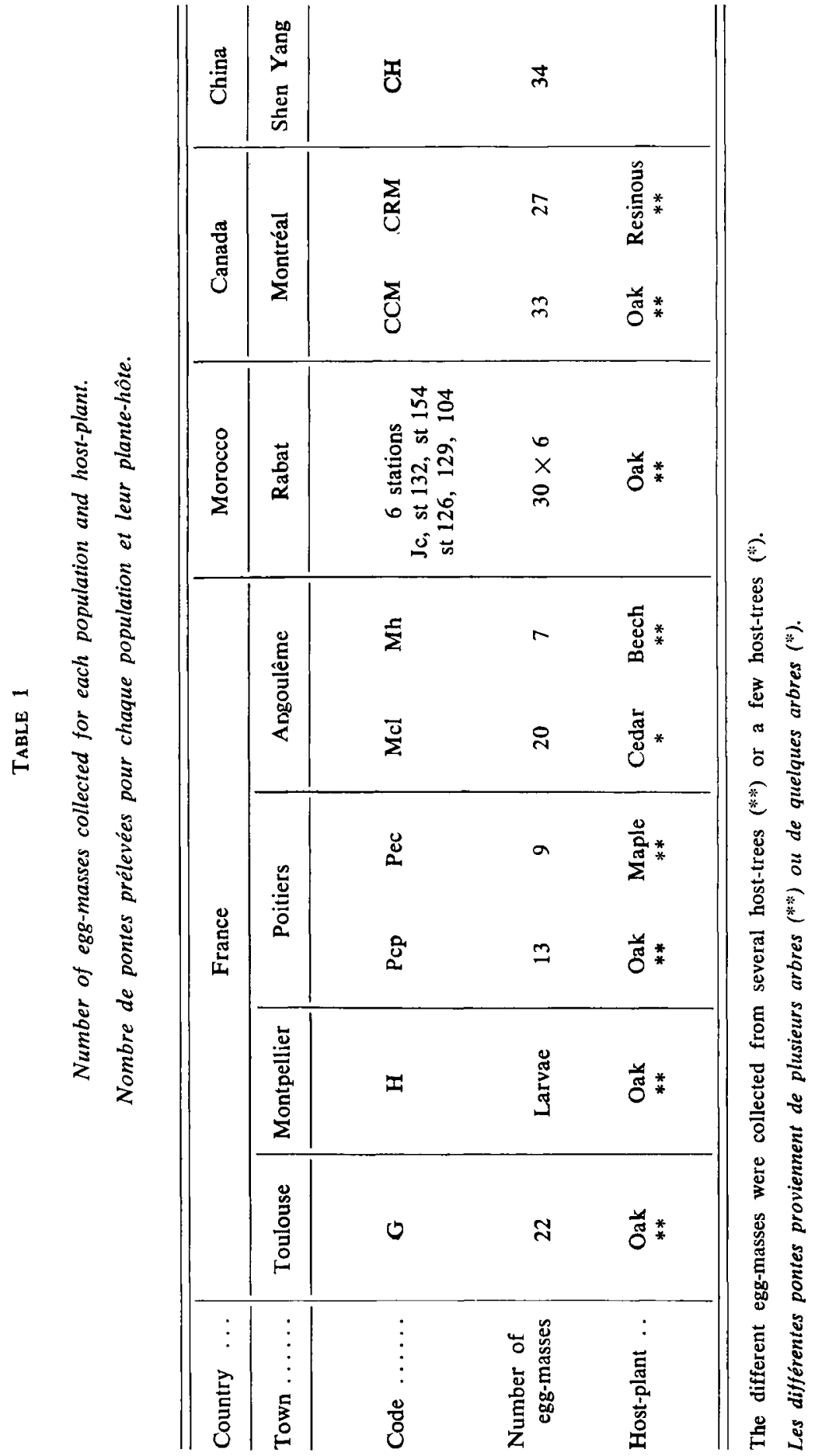




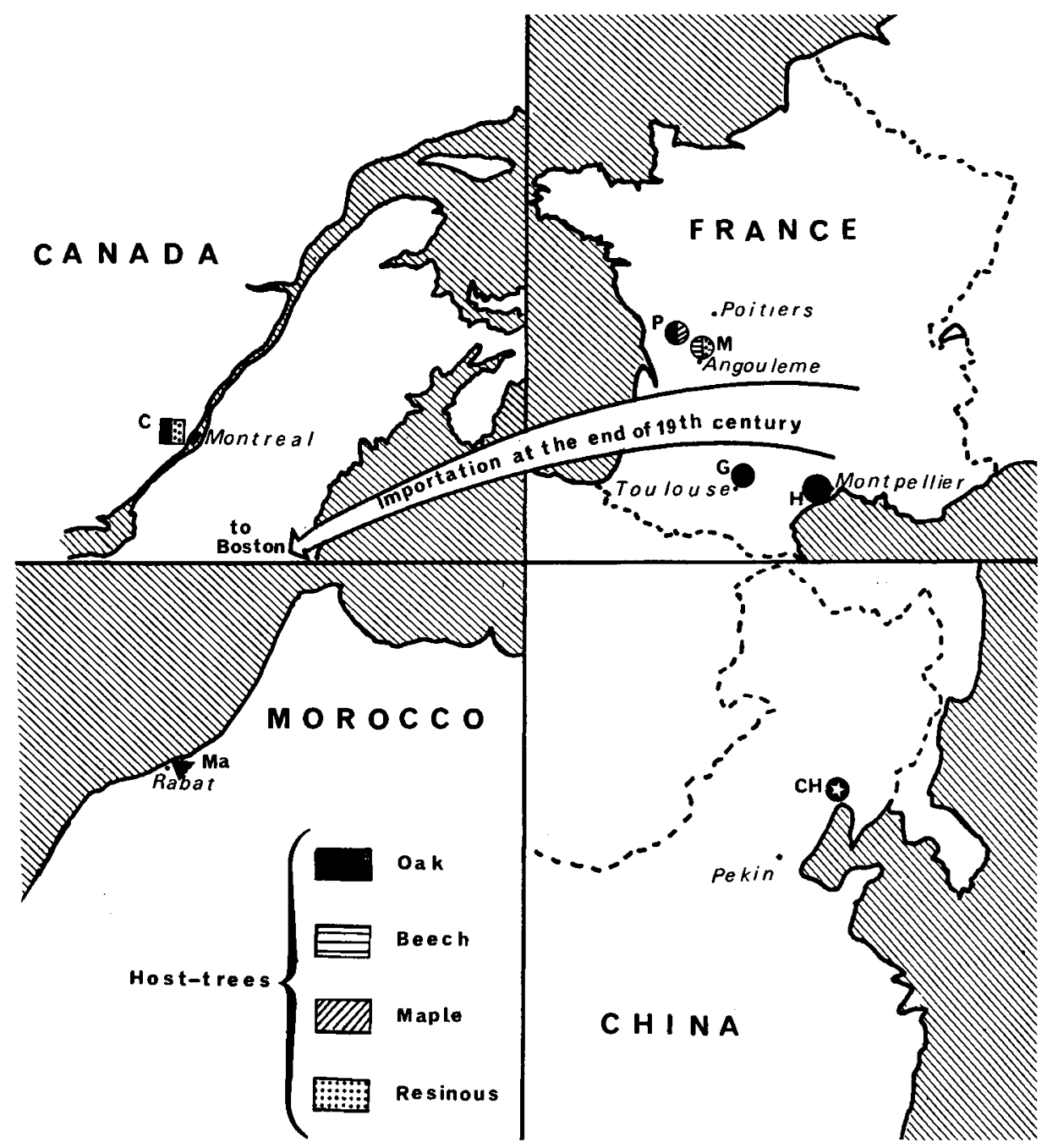

FIG. 1

Collection sites of Lymantria dispar populations used in this study.

Lieux de prélèvement des populations de Lymantria dispar utilisés dans cette étude.

Symbols are used to designate host-trees. The populations come from Canada, near Montreal $(C=C C M$ on oak and CRM on resinous $)$; from France near Poitiers $(P=P c p$ on oak and $\mathrm{Pec}$ on maple), near Angoulême $(\mathbf{M}=\mathbf{M c l}$ on cedar and $\mathrm{Mh}$ on beech), near Toulouse ( $\mathrm{G}$ on oak), near Montpellier $(\mathrm{H}=5$ th instar field-collected larvae); from Morocco near Rabat, in the Mamora forest $(\mathrm{Ma}=$ six stations : JC, st 132, st 154, st 104, st 126, st 129, all on oak) and from China in Shen Yang country (CH).

Des figurés sont utilisés pour désigner les plantes hôtes. Les populations proviennent du Canada, près de Montréal $(C=C C M$ sur chêne et $C R M$ sur résineux); de France, près de Poitiers $(P=P c p$ sur chêne et Pec sur érable $)$, près d'Angoulême $(M=M c l$ sur cèdre ct $M h$ sur hêtre), près de Toulouse $(G$ sur chêne), près de Montpellier $(H=$ chenilles de $5^{\circ}$ stade prélevées dans la nature); du Maroc près de Rabat, dans la forêt de la Mamora (Ma = six stations : JC, st 132, st 154, st 104, st 126, st 129, toutes sur chêne) et de Chine, de la province du Shen Yang $(\mathrm{CH})$ : 


\section{Results}

The ten loci code for four esterases, three leucine aminopeptidases, two acid phosphatases and one aspartate aminotransferase. The three-banded heterozygotes for Est-1 and Est-5 loci indicate that enzymes are at least dimers, the other enzymes being probably monomeric with two-banded heterozygotes. Among the ten loci, two are monomorphic (Est-2 and Aat), five are diallelic (Est-1, Est-5, Acph-4, Lap-2 and Lap-4), three alleles occur at Acph-6 and Lap-3 loci, Est-4 has four alleles including a «null» allele. The genetic determinism is supported by observing the egg-mass progenies. Since in Lymantria dispar multiple matings of females are rare (TAYLOR, 1967) each single egg-mass may be considered as progeny of a single mating. The genotype proportions appear to agree well with the expected Mendelian proportions (tabl. 2). Unfortunately, for Lap loci all the progenies observed in single egg-mass were monomorphic.

\section{TABLE 2}

Genotypic frequencies in some egg-masses and supposed mating with Chi-squared test of fit 1o Mendelian proportions, for three diallelic loci (Est-4, Est-5, Acph-4)

and a triallelic locus (Acph-6).

Fréquences des génotypes observés dans des pontes et les croisements supposés avec le test de $\chi^{8}$ de conformité aux proportions Mendéliennes pour trois locus dialléliques (Est-4, Est-5, Acph-4) et un locus triallélique (Acph-6).

\begin{tabular}{|c|c|c|c|c|c|c|c|c|c|c|}
\hline \multirow{2}{*}{ Locus } & \multirow{2}{*}{$\begin{array}{c}\text { Code } \\
\text { of egg-mass }\end{array}$} & \multirow{2}{*}{$\mathbf{N}$} & \multicolumn{6}{|c|}{ Observed genotypes } & \multirow{2}{*}{$\begin{array}{l}\text { Supposed } \\
\text { mating }\end{array}$} & \multirow{2}{*}{$\mathrm{X}^{2}$} \\
\hline & & & SS & SF & FF & MF & MM & MS & & \\
\hline \multirow[t]{3}{*}{ Est-4 } & H $81 \ldots$ & 16 & 0 & 7 & 9 & & & & $\mathrm{SF} \times \mathrm{FF}$ & 0.25 \\
\hline & $\mathrm{CB} \ldots \ldots$ & 26 & 6 & 12 & 8 & & & & $\mathrm{SF} \times \mathrm{SF}$ & 0.46 \\
\hline & $\mathrm{CC}_{3} \ldots \ldots$ & 16 & 3 & 8 & 5 & & & & $\mathrm{SF} \times \mathrm{SF}$ & 0.50 \\
\hline Est-5 & H $81 \ldots$ & 16 & 0 & 7 & 9 & & & & $\mathrm{SF} \times \mathrm{FF}$ & 0.25 \\
\hline Acph-4 & $\mathrm{Pcp}_{4} \ldots \ldots$ & 12 & 2 & 7 & 3 & & & & $\mathrm{SF} \times \mathrm{SF}$ & 0.49 \\
\hline \multirow[t]{5}{*}{ Acph- 6} & H 81 & 13 & 0 & 6 & 7 & & & & $\mathrm{SF} \times \mathrm{FF}$ & 0.88 \\
\hline & $\mathrm{Pcp}_{4} \ldots$ & 12 & 5 & 7 & & & & & $\mathrm{SF} \times \mathrm{SS}$ & 0.33 \\
\hline & $\mathrm{CB} \ldots \ldots$ & 22 & 3 & 14 & 5 & & & & $\mathrm{SF} \times \mathrm{SF}$ & 2.00 \\
\hline & $\mathrm{CC}_{1} \ldots \ldots$ & 20 & 5 & 6 & 0 & 4 & 0 & 5 & $\mathrm{SF} \times \mathrm{SM}$ & 0.40 \\
\hline & $\mathrm{CR}_{2} \ldots \ldots$ & 11 & 6 & 5 & & & & & $\mathrm{SF} \times \mathrm{SS}$ & 0.09 \\
\hline
\end{tabular}

The other egg-masses are monomorphic for the predominant allele in the population.

Les autres pontes sont monomorphes pour l'allèle prédominant dans la population.

S : Slower migrating allele (Est-4 ${ }^{99}$, Est- $5^{98}$, Acph-4 $4^{98}$, Acph-6 ${ }^{100}$ ). Allèle lent.

M : Medium migrating allele (Acph-6 $\left.{ }^{102}\right)$. Allèle moyen.

F : Faster migrating allele (Est-4 ${ }^{100}$, Est-5 ${ }^{100}$, Acph-4 $4^{100}$, Acph-6 $6^{104}$ ). Allèle rapide. 
疍|

\begin{tabular}{|c|c|c|c|c|}
\hline \multirow{2}{*}{ 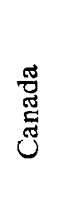 } & 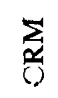 & $1-1 \mid q$ & 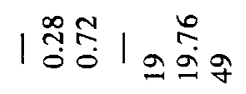 & $1-1 \mid$ g \\
\hline & $\sum_{U}^{\Sigma}$ & $I_{-} \mid I_{m}$ & 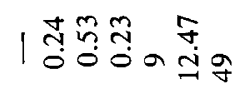 & $1-1 \mid g$ \\
\hline
\end{tabular}

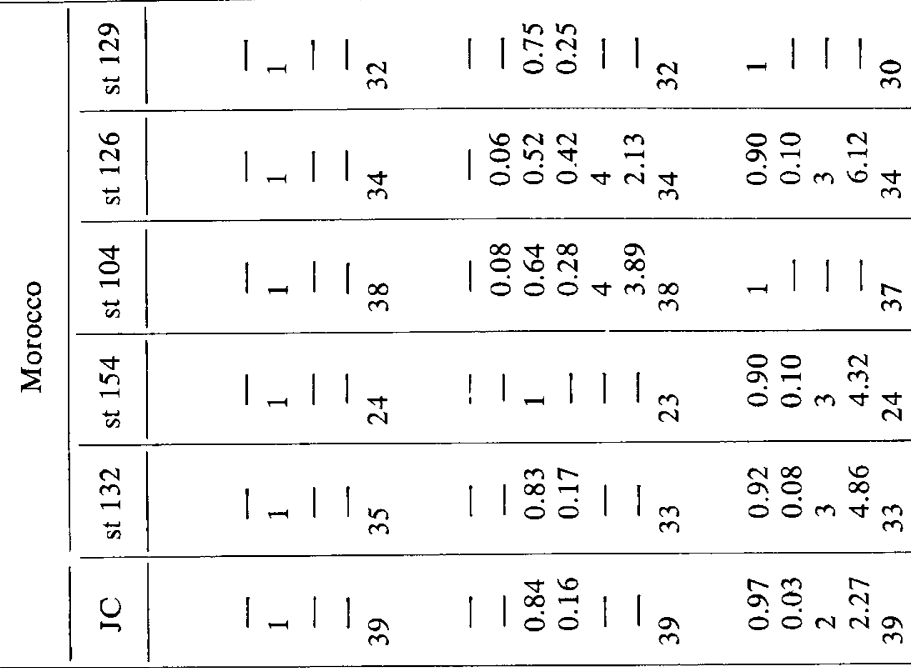

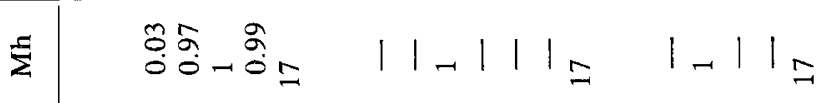

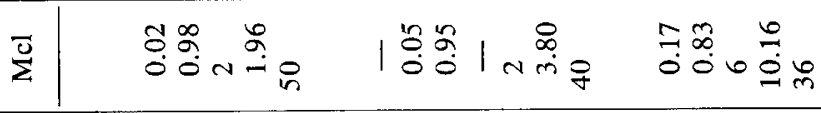

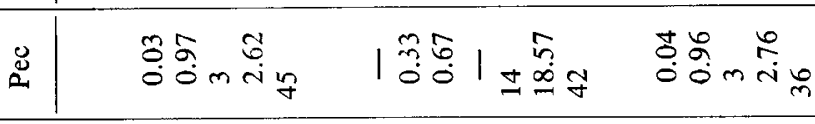

\begin{tabular}{|c|c|c|c|}
\hline- & $\begin{array}{r}\sigma \\
\end{array}$ & 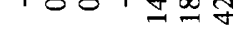 & 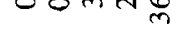 \\
\hline$\stackrel{0}{2}$ & 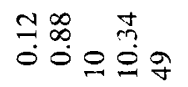 & 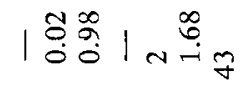 & ồं \\
\hline I & 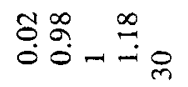 & |영 & గ̂̃ \\
\hline 0 & $|-1| \mathcal{y}$ & $\because\left|\begin{array}{c}\infty \\
0 \\
0\end{array}\right| \begin{array}{c}8 \\
0 \\
0\end{array}$ & ชัฒ \\
\hline
\end{tabular}

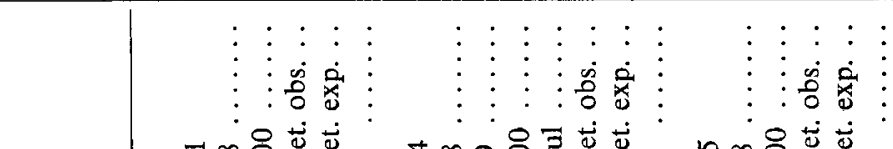

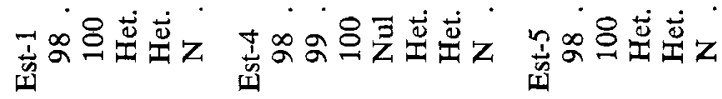




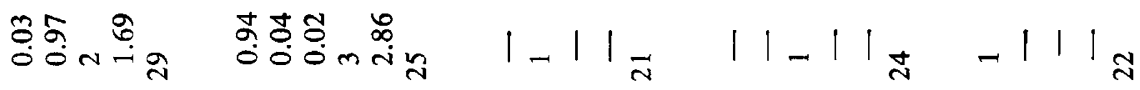

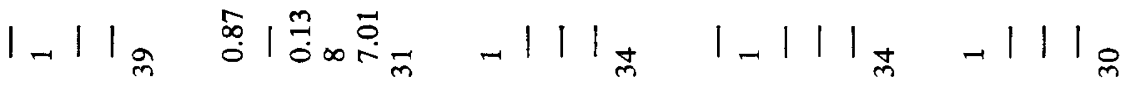

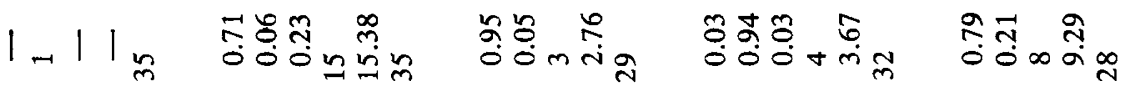

융요요

$1-1 \mid$ बे

焉

I- I

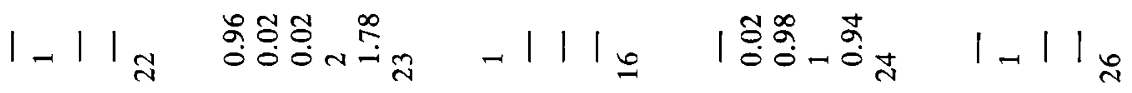

逭

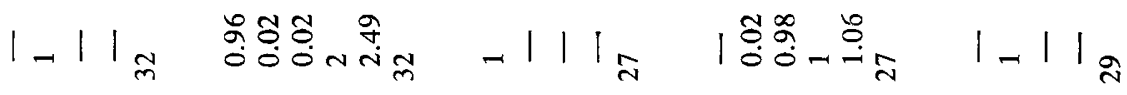

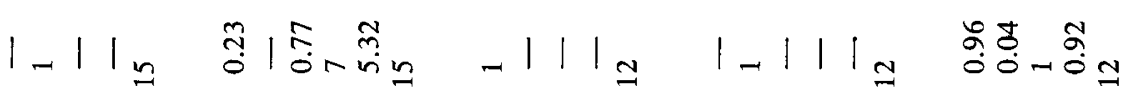

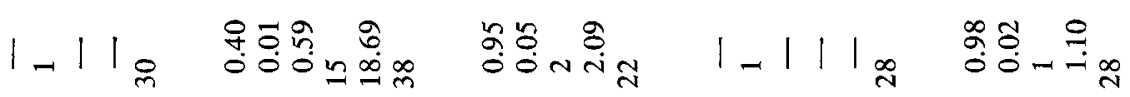

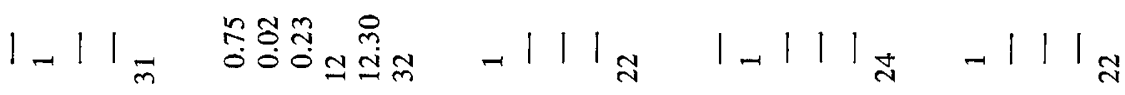

I-1 |

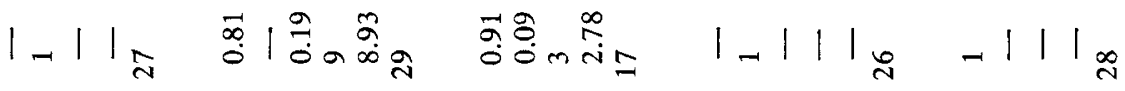

I- 1 | ल

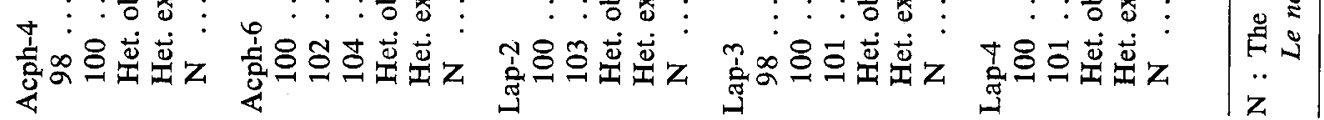


Allele frequencies for Est, AcPH and LAP loci are listed (tabl. 3). Each time it is possible to apply a statistical test, a Chi-squared test of fit to Hardy-Weinberg law shows agreement between observed and expected genotype distributions. The polymorphism level is estimated by reference to two values : the polymorphic loci proportion and the heterozygosity (tabl. 4). Overall populations the average heterozygosity is 0.09 (ranging from 0.03 to 0.16 ).

\section{TABLE 4}

Level of polymorphic loci and heterozygosity in natural populations of Lymantria dispar from France, Morocco, Canada and China.

Taux de locus polymorphes et hétérozygosité dans des populations de Lymantria dispar.

\begin{tabular}{|c|c|c|c|c|}
\hline \multirow[t]{2}{*}{ Country } & \multirow[t]{2}{*}{ Population } & \multicolumn{2}{|c|}{$\begin{array}{c}\text { Proportion } \\
\text { of polymorphic loci }\end{array}$} & \multirow[t]{2}{*}{ Heterozygosity } \\
\hline & & (1) & (2) & \\
\hline \multirow[t]{6}{*}{ France } & $\operatorname{Pcp} \ldots \ldots \ldots$ & 0.60 & 0.20 & 0.09 \\
\hline & $\operatorname{Pec} \ldots \ldots \ldots$ & 0.40 & 0.20 & 0.10 \\
\hline & $\mathrm{Mcl} \ldots \ldots \ldots$ & 0.60 & 0.40 & 0.10 \\
\hline & Mh $\ldots \ldots \ldots$ & 0.30 & 0.10 & 0.05 \\
\hline & $G \ldots \ldots \ldots$ & 0.60 & 0.30 & 0.10 \\
\hline & $\ldots \ldots \ldots$ & 0.50 & 0.40 & 0.12 \\
\hline \multirow[t]{6}{*}{ Morocco } & st $154 \ldots \ldots \ldots$ & 0.30 & 0.10 & 0.03 \\
\hline & st $132 \ldots \ldots \ldots$ & 0.40 & 0.30 & 0.07 \\
\hline & $\mathrm{JC} \ldots \ldots \ldots$ & 0.40 & 0.10 & 0.04 \\
\hline & st $104 \ldots \ldots \ldots$ & 0.40 & 0.30 & 0.11 \\
\hline & st $126 \ldots \ldots \ldots$ & 0.30 & 0.20 & 0.08 \\
\hline & st $129 \ldots \ldots \ldots$ & 0.30 & 0.30 & 0.09 \\
\hline \multirow[t]{2}{*}{ Canada } & $\mathrm{CCM} \ldots \ldots$. & 0.50 & 0.50 & 0.16 \\
\hline & CRM $\ldots \ldots$ & 0.50 & 0.20 & 0.06 \\
\hline Chine & CH $\ldots \ldots \ldots$ & 0.40 & 0.30 & 0.11 \\
\hline
\end{tabular}

The predominant allele frequency must be equal or lower (1) than 99 p. 100 (2) than 95 p. 100 (Ayala, 1975).

La fréquence de l'allèle prédominant doit être égale ou inférieure (1) à 99 p. 100, (2) à 95 p. 100 (Ayala, 1975).

No allele is diagnostic for a particular population or region. Nevertheless, significant geographical variations can be observed between the different regions at several loci. Est-598 allele has generally a low frequency in all populations but those of Morocco ; Lap-2 ${ }^{103}$ is rare in all populations except China ; Lap-3100 is common in France and Canada but rare in Morocco and absent in China. Finally, the Moroccan population is homozygous for the Lap- $4^{101}$ allele which has a low frequency in France and is absent in China. 


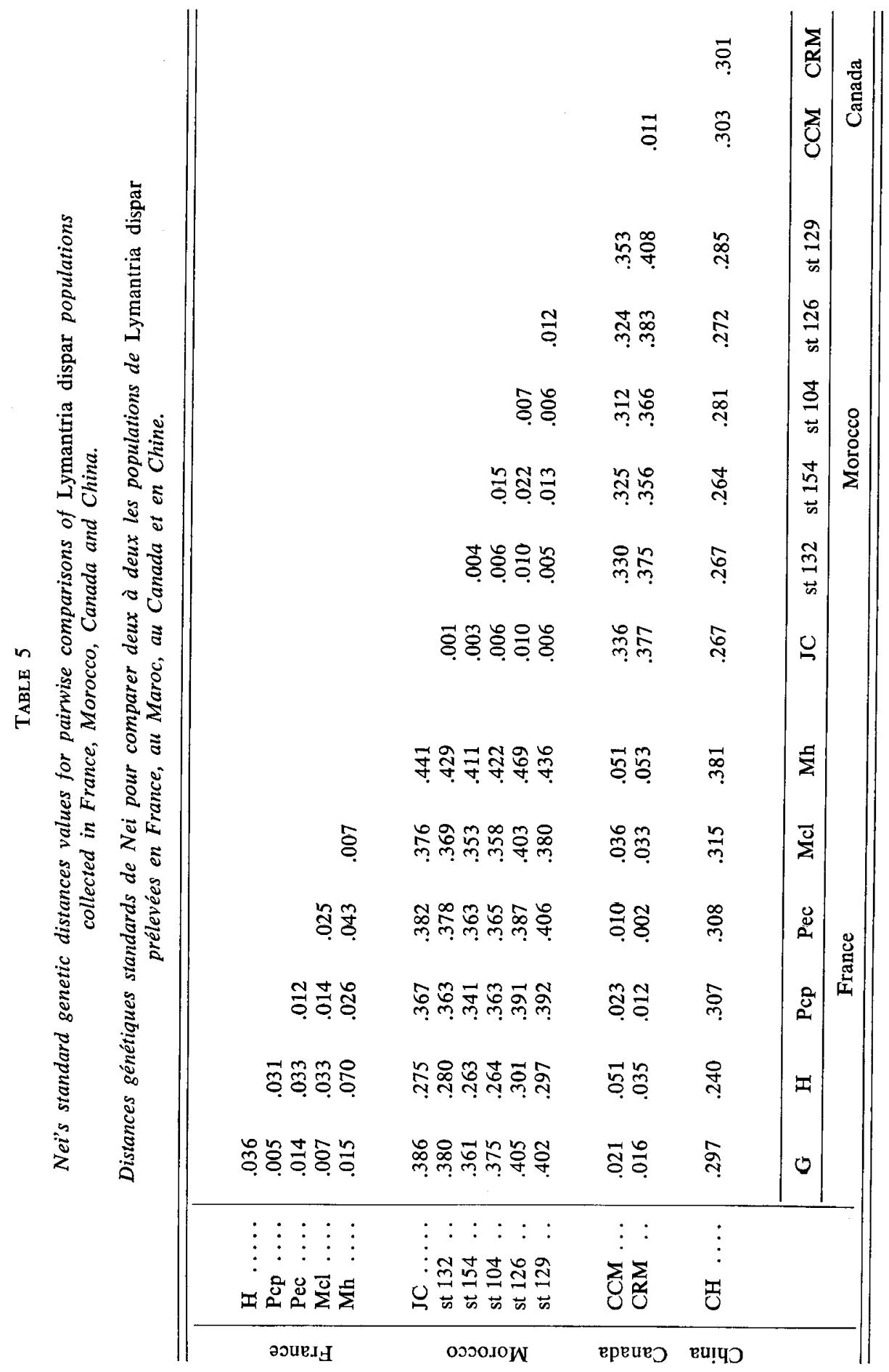


Nei's standard genetic distances (1972) were computed to estimate the genetic differentiation between the various populations (tabl. 5). The genetic distances vary from 0.001 to 0.469 . Intraregional differentiation are usually lower $(\bar{D}=0.025$ in France and $\overline{\mathrm{D}}=0.008$ in Morocco) than those observed between populations collected in different geographical areas $(\overline{\mathrm{D}}=\mathbf{0 . 2 7 3}$, ranging from 0.029 between France and Canada, to 0.370 between France and Morocco) with the noticeable exception of the Canadian and French populations which are very similar $(\overline{\mathrm{D}}=0.029)$. A principal coordinates analysis (Gower, 1966) discriminates three well individualised groups (fig. 2) : Morocco on the right, China in the middle of the plan, the French and Canadian populations being close together on the left.

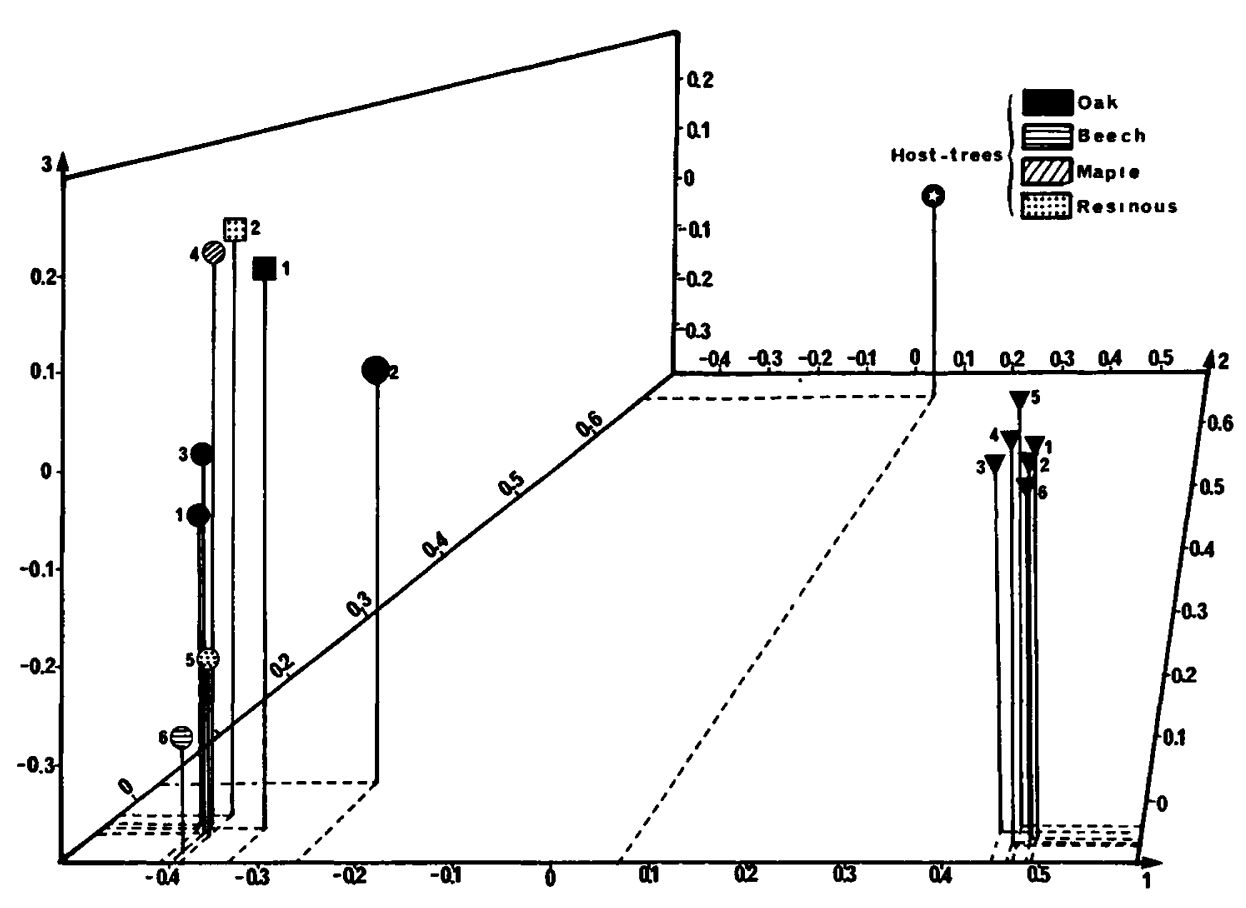

Fig. 2

Principal coordinates analysis of the populations of Lymantria dispar Analyse en coordonnées principales de populations de Lymantria dispar

(O) From France $(1=\mathrm{G}, 2=\mathrm{H}, 3=\mathrm{Pcp}, 4=\mathrm{Pec}, 5=\mathrm{Mcl}, 6=\mathrm{Mh})$. De France $(l=G, 2=H, 3=P c p, 4=P e c, 5=M c l, 6=M h)$.

(口) From Canada $(1=\mathrm{CCM}, 2=\mathrm{CRM})$. Du Canada $(1=C C M, 2=C R M)$.

(v) From Morocco $(1=\mathrm{JC}, 2=\mathrm{st} 132,3=\mathrm{st} 154,4=\mathrm{st} 104,5=\mathrm{st} 126,6=\mathrm{st} 129)$. Du Maroc $(1=J C, 2=s t 132,3=s t 154,4=s t 104,5=s t 126,6=s t 129)$.

(®) From China. De Chine. 
In three populations (Angoulême, Poitiers and Canada) the eggs collected from two different hosts in the same forest show differences in the allele frequencies at Est-4 and Lap-4 loci. The Est-499 allele frequency is significantly lower in oak sample than in maple sample in the French population from Poitiers. In the Canadian population the Est- $4^{99}$ allele frequency is also lower in oak sample, but the occurence of Est- $4^{\text {null }}$ allele in the oak sample, with a relatively high frequency, can complicate the result. The Lap-4 is quite monomorphic in French populations, so no significant difference can be expected between the oak and other samples. In the Canadian population, the Lap-4100 and Lap-4101 allele frequencies differ significantly between oak and resinous samples. In the same population the Est-4, Acph-5, Lap-3 (three triallelic loci) and Lap-2, Lap-4 (two diallelic loci) in oak sample become respectively diallelic or monomorphic loci in the resinous sample. In all, six alleles were not detected in the pine-tree sample. Moreover, the multi-dimensional analysis (fig. 2) shows that the vertical axis tends to discriminate the gypsy moth populations according to their host plant : the egg-masses collected on oak, except the Canadian population (CCM), seem all close to the zero of the vertical axis while the others are distributed on both sides. The studied larvae descending from these field-collected egg-masses were reared on the same artificial diet in similar conditions. Thus it is assumed that no differences in genotype mortality occur and the observed differences in larvae correspond to differences in populations of their parents. Since the female of Lymantria dispar does not fly and the larvae very often feed on the same tree throughout their life, we assume that the mothers of egg-masses collected from oak (for example) grow on the same tree.

\section{Discussion}

The level of genetic variability in Lymantria dispar is lower than in other Lepidoptera such as Pectinophora gossypiella $(\overrightarrow{\mathrm{H}}=0.37$; BARTLETT, 1981) but closer to the estimates given for Drosophila $(\overline{\mathrm{H}}=0.145$; Wagner \& SElander, 1974). The lower values of the heterozygosity are due to small allele number per locus and above all, because one allele is strongly predominant in many loci.

In three populations, frequency differences are observed among eggs collected from different hosts. These differences suggest a possible association between the host and allozyme frequencies. Associations between the host and fitness characteristics of the moth have been reported. BARBOSA et al. (1979) have shown that the development and survival of gypsy moth larvae are strongly influenced by the host plant upon which they feed, especially the rate of dispersion of the first instar (LANCE \& BARBosa, 1981). VALENTINe \& HUSTON (1979) found that the quality and quantity of certain structural features on trees used by Lymantria dispar are very important for resting, pupation and oviposition. These authors consider that white oak (Quercus alba) and chestnut oak ( $Q$. pinus) are superior habitats. Some hypothesis have to be put forward to explain the genetic differences observed. Perhaps host plant races occur within Lymantria dispar. These are not uncommon amongst lepidoptera, particularly in monophagous macrolepidoptera taxa (HollowAY \& HEBERT, 1979). If there are no host races, the explanation could be differential attraction of genotypes to different trees rather than founder effects, since the species is quite vagile (LEONARD, 1974). These results in $L$. dispar are similar to those observed in 
Heliothis virescens (Sluss \& GraHam, 1979). Different allele frequencies are found between larvae collected from cotton and wild tobacco but there is no evidence of host-plant race formation. However, this study of the gypsy moth does not allow affirm conclusion regarding the absence or the existence of host races. Further experiments on other populations are obviously needed to test for host association with the genetic constitution of the population.

The intraregional differentiation between populations of Lymantria dispar are very low in Morocco $(\overline{\mathrm{D}}=0.008)$, possibly due to the fact that the six stations were located in the same forest. The genetic differentiation between French populations are also low $(\overrightarrow{\mathrm{D}}=\mathbf{0 . 0 2 5})$ in spite of their geographical remoteness and of the forests composed of different tree-species. These distances are similar to those observed between local populations of Heliothis virescens $(\bar{D}=0.034$; Sluss \& GRAHAM, 1979) or of Pectinophora gossypiella ( $\overline{\mathrm{D}}=0.021$; BARTLETT, 1981). A comparable genetic distance is also found between the subspecies of Speyria $(\overline{\mathrm{D}}=0.023$; BRITTNaCHER et al., 1977). Similarly Nei's standard genetic distance estimate for the Drosophila willistoni group is 0.031 for local populations (AYALA et al., 1974). The gypsy moth data suggest that dispersal between populations is sufficient to maintain genetic similarity.

By their slight genetic distance $(\overline{\mathrm{D}}=0.029)$, French and Canadian samples can be considered as local populations. This result supports the French origin of Canadian populations. Over one century, there has been no significant overall divergence between the populations of these two countries. It seems that there has been no founder effect or perhaps successive colonisations may have occurred. We observe a significant difference in the allele distributions between the French and the Canadian samples, on the same host tree at Est-4 locus. Perhaps the enzymatic variants of this locus have a selective value. More experiments are necessary to assess this point.

By contrast, the genetic distance between France and Morocco $(\overline{\mathbf{D}}=0.370$; ranging from 0.263 to 0.469$)$ or between France and China $(\overline{\mathrm{D}}=0.308$; ranging from 0.240 to 0.381 ) are large and higher than distances between species of Speyria $(\overline{\mathrm{D}}=0.182$; BRITTNACHER et al., 1977), or between species of Choristoneura group $(\bar{D}=0.075 ;$ Stock \& CaSrovillo, 1981). These species are defined by characters conventionally used in taxonomy. Nevertheless SLuss et al. (1978) found a larger distance $(\overline{\mathrm{D}}=0.874)$ between Heliothis virescens and H.zea. Ayala (1975) shows distances similar to our results between subspecies of Drosophila willistoni group. The genetic distances between the French and Chinese or between Moroccan and Chinese populations are similar. It could be a result of long established separation or, more simply, it is an indication of the large geographical and ecological distance which separates these countries ; the gene flow is slow between them. Likewise TEssiER (1958) found same important physiological, anatomical and morphological differences between the French and Japanese populations of Drosophila melanogaster.

For the populations of France and Morocco, while the geographical distance is lower than between France and China, the Nei's standard distance is higer. Given $\overline{\mathbf{D}}$ values as high as those reported between species, this result highlights the problem of the taxonomic status of both populations. Two hypothesis should be stated. First, if there is no significant reproductive isolation, there exists definite environmental factors different between both countries which could cause the genetic difference. Under this hypothesis there may well be a clinal change in these factors through Europe which would lead to a genetic cline in Spain. For other characters, GoldschmidT (1934) 
has shown a clinal variation in the Japanese Islands. On the other hand, there may be two species, in which case a genetic cline would not be predicted. The two forms should occurred in Spain with perhaps a zone of sympatry and the occurrence of isolation mechanisms.

\section{Conclusion}

These data suggest that significant geographical variation exist in natural populations of Lymantria dispar, in particular between French and Moroccan populations, raising the problem of taxonomic status of both. Thus this investigation has provided the first elements of a new aspect of Lymantria dispar speciation. Many more studies are still needed on a larger number of populations throughout the world, in particular from Spain, and on other enzymatic systems.

\section{Acknowledgements}

The author wishes to thank M. Guillaumin, J.L. Clement, M.L. Cariou, J.P. Simon and D. Roby for their help in her research, Mr Fraval, Minet, Xiao Gang-Rou and Mrs NiveT for Lymantria dispar collections and M. LEFEVRE for the mathematical analysis of the results.

Received August 1, 1983.

\section{References}

AYala F.J., 1975. Genetic differentiation during the speciation process. Evol. Biol., 8, 1-78.

Ayala F.J., Powell J.R., Tracey M.L., Mourao C.A., Perezsalas S., 1972. Enzyme variability in the Drosophila willistoni group. IV. - Genic variation in natural populations of Drosophila willistoni. Genetics, 70, 113-139.

Ayala F.J., Tracey M.L., Hedgecock D., Richmond R.C., 1974. Genetic differentiation during the speciation process in Drosophila. Evolution, 28, 576-592.

Barbosa P., Greenblatt J., Withers W., Cranshaw W., Harrington E., 1979. Hostplant preferences and their induction in larvae of gypsy moth Lymantria dispar. Entomol. Exp. Appl., 26, 180-188.

BARTLETT A.C., 1981. Isozyme polymorphism in population of the pink bollworm. Ann. Entomol. Soc. Am., 74, 9-13.

Brittnacher J.G., Sims S.R., Ayala F.J., 1977. Genetic differentiation between species of the genus Speyria (Lepidoptera : Nymphalidae). Evolution, 32, 199-210.

Davies B.J., 1964. Disc electrophoresis. II. - Method and application to human serum proteins. Ann. N.Y. Acad. Sci., 121, 404-427.

E-C Apparatus Corp., 1966. Discontinuous vertical gel electrophoresis system. E-C Apparatus Corporation Bull., 11, 1.

George C., 1982. Polymorphisme enzymatique de Lymantria dispar L. (Lep. Lymantriidae). Thèse Doctorat $3^{\ominus}$ cycle, Université Paris VII. 
GIRARD P., 1976. Etude du polymorphisme enzymatique de quinze populations naturelles françaises de Drosophila melanogaster. Thèse Doctorat $3^{\circ}$ cycle, Université Paris VII.

GoldSChmidT R.B., 1934. "Lymantria dispar». Bibliogr. Genet., 11, 1-186.

Grower J.C., 1966. Some distance properties of latent root and vector methods used in multivariate analysis. Biometrika, 53, 325-338.

Holloway J.D., Hebert P.D.N., 1979. Ecological and taxonomic trends in macrolepidopteran host plant selection. Biol. J. Linn. Soc., 11, 229-251.

Lance D., Barbosa P., 1981. Host tree influences on the dispersal on first instar gypsy moths, Lymantria dispar (L.). Evol. Entomol., 6, 411-416.

LEONARD D.E., 1974. Recent developments in ecology and control of gypsy moth. Annu. Rev. Entomol., 19, 177-229.

MC Kechnie S.W., Ehrlich P.R., White R.R., 1975. Population genetics of Euphydryas butterflies. I. - Genetic variation and the neutrality hypothesis. Genetics, 81, 571-594.

NeI M., 1972. Genetic distance between populations. Am. Nat., 106, 283-292.

Ornstein L., 1964. Disc electrophoresis. I. - Background and theory. Ann. N.Y. Acad. Sci., 121, 321-349.

Pasteur N., Kastritsis C., 1971. Developmental studies in Drosophila. I. - Acid phosphatases, esterases and other proteins in organs and whole-fly homogenates during development of D. pseudoobscura. Dev. Biol., 26, 525-536.

Shaw C.R., Prasad R., 1970. Starch gel electrophoresis of enzymes. A compilation of recipes. Biochem. Genet., 4, 297-320.

Simon J.P., 1969. Esterase isozymes in mosquito Culex pipiens fatigans developmental and genetic variation. Ann. Entomol. Soc. Am., 62, 1307-1311.

Sluss T.P., Graham H.M., 1979. Allozyme variation in natural populations of Heliothis virescens. Ann. Entomol. Soc. Am., 72, 317-322.

Sluss T.P., Sluss E.S., Graham H.M., Dubors M., 1978. Allozyme differences between Heliothis virescens and H. zea. Ann. Entomol. Soc. Am., 71, 191-195.

Stock M.W., Casrovillo P.J., 1981. Genetic relationships among representative populations of five Choristoneura species : C. occidentalis, C. retinianana, C. biennis, C. lambertiana and C. fumiferana (Lepidoptera : Tortricidae). Can. Entomol., 113, 857-865.

TAYLOR O.R., 1967. Relationship of multiple mating and fertility in Atteva punctella. Ann. Entomol. Soc. Am., 60, 583-590.

TeSSIER G., 1958. Distinction biométrique des Drosophila melanogaster françaises et japonaises. Ann. Genet., 1, 2-10.

Valentine H.T., Houston D.R., 1979. A discriminant function for identifying mixed-oak stand susceptibility to gypsy moth defoliation. For. Sci., 25, 468-474.

WAGNer R.P., Selander R.K., 1974. Isozymes in insect and their significance. Annu. Rev. Entomol., 19, 117-138. 